Ege Tıp Dergisi / Ege Journal of Medicine 2019; 58: Ek Sayı / Supplement 14-21

\title{
Osteoartrozda yeni tedavi yöntemleri
}

\author{
New therapy methods in osteoarthritis \\ Diren Özer@ Sibel Eyigör \\ Ege Üniversitesi Tıp Fakültesi, Fiziksel Tıp ve Rehabilitasyon Anabilim Dalı
}

\section{Öz}

Osteoartroz (OA) en yaygın artrit şeklidir. OA'da klinik çalışmaların sunduğu birçok zorluğa rağmen, hastalık patogenezi, hastalık süreci ve ağrının tedavisinin yanı sıra altta yatan hastalığın tedavisinde birçok yeni farmakolojik tedaviler ve klinik araştırmalar vardır. Yeni farmakolojik ajanlar ile klinikte OA'da semptomların ve hastalık sürecinin iyileştirilmesine yönelik fırsatlar ufukta görünmektedir.

Anahtar Sözcükler: Osteoartroz (OA), ilaç, klinik çalışma, tedavi.

\begin{abstract}
Osteoarthritis $(O A)$ is the most common form of arthritis. Despite the many challenges presented by clinical trials in $O A$, improvements in our understanding of disease pathogenesis and a move to treat pain, as well as underlying disease process, mean there are now many new pharmacological therapies currently in various stages of clinical trials. Some challenges remain, but opportunities for improving symptoms and disease process in OA in the clinic with new pharmacological agents would appear to be on the close horizon.
\end{abstract}

Keywords: Osteoarthritis (OA), drug, clinical trial, treatment.

\section{Giriş}

Osteoartroz (OA) en sık görülen artrit şekli olup, 45 yaş üzeri kişilerin üçte birinde, ciddi özürlülük ve sağlık hizmetleri maliyetine neden olmaktadır. Yaşlı ve obez popülasyonun semptomatik $O A$ insidansı ve eklem protez ameliyatlarının yüksek maliyetleri her yıl giderek artmaktadır. OA günümüzde henüz eklem artroplastisi için uygun olmayan 40 ve 50 yaşlarındaki genç insanlarda görülen bir hastalık haline gelmiş olup, bu durum yeni farmakolojik tedavilere artan karşılanmamış bir intiyaca yol açmaktadır. OA için daha iyi ilaç tedavileri geliştirmek üzere uluslararası alanda büyük bir ivme vardır. Farklı ilaç sınıfındaki bir dizi ajan, OA'un medikal tedavi seçenekleri hakkında düşünme biçimimizi değiştirecek gibi görünmektedir. $\mathrm{OA}$ için ilaç tedavileri; ağrı veya semptomları iyileştiren ve yapısını iyileştiren, ilerlemesini yavaşlatan, ağrıya etkisi olan veya olmayan gruplara ayrılabilir. OA yönetimi için mevcut kurallar arasında hastalık için çeşitli farmakolojik tedavilerden önce her zaman eğitim, kilo kaybı ve egzersiz önerileri verilmelidir (1).

Yazışma Adresi: Sibel Eyigör

Ege Üniversitesi Tıp Fakültesi, Fiziksel Tıp ve Rehabilitasyon Anabilim Dalı

E-mail: eyigor@hotmail.com
Ağrısı yeterince kontrol edilmeyenlerde, birinci basamak kanıta dayalı analjezi, topikal steroid olmayan antiinflamatuvar ilaçlar (NSAil'lar) ve asetaminofen (parasetamol) kullanılır. Oral NSAil'lar ve siklooksijenazII (COX-II) inhibitörleri, opiyatlar veya eklem içi steroidlerin kullanımı birinci basamak ajanların başarısız olması durumunda göz önünde bulundurulur. Bununla birlikte, bu ajanların en iyisi bile, ilacı alanların ancak yarısında klinik olarak anlamlı bir etki sağlar ve yan etkileri, potansiyel toksisiteleri, sık sık eşlik eden komorbiditeleri olduğu için popülasyonda kullanımları sınırlanır. Belirgin ağı, bozulmuş yaşam kalitesi, ileri radyografik hastalığı olanlarda total diz veya kalça protezi, çoğunlukla semptomlarda önemli iyileşme sağlar ancak büyük bir operasyonun ilgili maliyetlerini ve risklerini taşır. Bununla birlikte, hala önemli bir tedavi açığı kalmaktadır: semptomatik hastalığı olan genç (< 55 yaş) hastalar ve her yaşta semptomatik olan fakat radyografik olarak protez için hastalık görüntüsü olmayan hastalar. Radyografik hastalığı olanların hepsinin ilerlemediğini not etmek önemlidir; yeni medikal tedaviler bu grubu arttırabilir ve sonuçta ameliyat gerektiren hasta sayılarını azaltabilir $(2,3)$.

\section{Osteoartroz için Hedef Doku ve Moleküller}

Osteoartroz, eklem kıkırdağı, subkondral kemik, sinoviyum, ligament ve menisküs gibi diğer yumuşak dokuları etkileyen, hepsinin hastalığın patogenezinde önemli olduğu gösterilen tüm eklemin hastalığıdır. İlgili üç moleküler süreç, inflamasyon, onarım-yeniden şekillenme ve ağrı üreten yollar, tüm bu eklem bağ 
dokularında önemli moleküler hedeflerdir (3). OA tüm eklemin bir hastalığı olarak kabul edilir, etkilenen bağ dokularının çoğu yeni ilaçlar için hedef olur. Eklem kıkırdağındaki değişiklikler hastalığın erken dönemlerinde meydana gelir. Yapısal olarak tehlikeye giren eklem kıkırdağı daha fazla hasara karşı savunmasızdır. Kemik yeniden şekillenmesi hastalığın erken döneminde ortaya çıkar ve eklem kıkırdağındaki değişiklikleri yakından yansıtır. Manyetik rezonans görüntülemede (MRG) ortaya çıkan kemik iliği lezyonları ağrı ve progresyon ile ilişkilidir ve osteofit formasyonu da dahil olmak üzere yeni kemik oluşumu meydana gelir (4). Bu tür bir yeniden yapılanma bir tamir girişimi olarak görünmektedir; bunun bazen yararlı olup olmadığı, bir eklemin stabilize edilmesi veya parçalanması ya da her zaman bir ağrı ve diğer semptomların ana itici gücü olup olmadığı tartışma konusudur. Ağrı, yapı veya her ikisini de hedef alan ilaç örnekleri ile kıkırdak, kemik, iltihap / onarım ve ağrı ile ilgili terapötik hedefler kısaca gözden geçirilecektir $(1,5)$.

\section{Kemik}

OA tedavisinde kemiği hedeflemenin gerekçesi, subkondral kemik ve kıkırdak arasındaki moleküler ve OA'un gelişiminde erken bir aşamada meydana gelen subkondral kemik rezorpsiyonu üzerine kuruludur. Bazı OA formlarının erken evrelerinde subkondral kemik metabolizmasının anormallikleri, özellikle artmış kemik döngüsü tespit edilmiştir. Bu çalışmalar, subkondral kemiğin eklem hastalığının ilerlemesi için önemli olduğu ve kıkırdak yıkımına neden olan faktörlerin subkondral kemikten gelebileceği hipotezini desteklemektedir (6). Osteoporoz ve OA'da, hem yüksek hem de düşük kemik kütlesi koşulları, hastalığın indüklenmesine ve / veya ilerlemesine neden olabilmektedir. Tedavide hedef olarak kemiğe en büyük desteği veren iki ilaç sınıfının, bifosfonatlar ve stronsiyum ranelat olduğu görülmektedir $(2,7)$. Risedronat ile yapılan çalışmalarda temel hedefleri tam olarak karşılamadığı belirtilmektedir. Ancak bazı hastalarda etkili olduğu ve aynı zamanda kollajen Tip II'nin C-terminal çapraz bağlanma telopeptidinde (kemikteki değişiklikleri yansıtabilen nitelikli bir kıkırdak biyobelirteç) baskılayıcı etkilere sahip olduğu görülmüştür (8). Yakın zamanlarda, sistemik olarak uygulanan bifosfonatların iki çalışmasında OA ağrısı üzerinde önemli etkiler bildirilmiştir. İntravenöz zoledronat ile tedavi edilen bireylerin bir yıl boyunca görsel analog skala (VAS) ağrısı ve kemik iliği lezyonlarını azalttığını bildirmiştir. Neridronat ile, MRG skoru, VAS ağrısı ve kemik iliği lezyonlarında iyileşme görülmüştür. Intraartiküler uygulanan klodronat da kıkırdak ve fonksiyonlar açısından fayda göstermiştir. Bisfosfonatın intraartiküler kullanımı ile ilgili yapılmış çalışmada diz ağrısında azalma ile de ilişkili bulunmuştur (9). Stronsiyum ranelat ile yapılan çalışmalarda OA'da radyografik olarak önemli bir iyileşme olduğu belirtilmektedir. Diz OA'unda (SEKOIA çalışması) ilacın
$1 \mathrm{~g}$ veya $2 \mathrm{~g}$ etkileri incelenmiştir. Paradoksal olarak, kemik yapısı $1 \mathrm{~g}$ ile düzelmiş, ancak ağrı yararı sadece 2 $\mathrm{g}$ ile görülmüştür. $2 \mathrm{~g}$ dozda ağrı, fonksiyon ve sertlikte klinik olarak anlamlı bir iyileşmeye dikkat çekmişlerdir. MRG sonuçları kullanılarak yapılan post-hoc analizlerde, her iki dozun da kemik iliği lezyonları üzerinde önemli etkileri olmuştur. Güvenlik endişeleri, venöz tromboembolizm, DRESS, cilt reaksiyonları, nöbet ve hafıza kaybı riskinin arttığı raporları bulunmaktadır (2, 10). Çalışmalar 3-4 yıl boyunca günde $2 \mathrm{~g}$ stronsiyum alan hastaların pıhtılaşma yan etkileri ve sinir sistemi yan etkileri (nöbetler) açısından daha yüksek risk altında olduğunu göstermektedir. 2014 yılında, ilaç venöz tromboembolizm ve miyokard enfarktüsü riskine ilişkin güvenlik endişeleri nedeniyle birincil osteoporoz endikasyonu ile sınırlandırılmıştır. Sonuç olarak OA'daki program şu anda beklemededir $(1,11)$. Bu alanda etki saptanmayan çalışmalar da yapılmıştır. Diğer bir osteoporotik ajan olan Salmon kalsitonini, diz OA çalışmasında plasebodan anlamlı bir farklılık göstermemiştir. D vitamininin ağrıyı azaltacağı ve potansiyel olarak hastalığın değiştirebileceği konusunda çok sayıda kanıt vardır (12). Bununla birlikte, son iki çalışmada oral D vitamini serum seviyelerini anlamlı şekilde arttırılması Batı Ontario ve McMaster Üniversiteleri Artrit İndeksi (WOMAC) değerlendirmesinde ağrı veya kıkırdak hacminde anlamlı bir fark yaratmamıştır. İzolikuiritigenin, subkondral kemikte, kemik rezorbsiyonu ve anjiyogenez üzerine etki ederek osteoartroz tedavisinde etkili olabileceğini gösteren sonuçlar bulunmaktadır $(1,2,13)$.

\section{Kıkırdak}

Eklem kıkırdağında hastalık modifikasyonunun sağlanması üzerinde uzun süredir durulmaktadır. 2005 yılında iki raporda, fare OA'da görülen agrekanın spesifik bölünmesinden sorumlu olan temel enzimintrombospondin motifleri-5 (ADAMTS-5)- inhibe edilmesinin $O A$ gelişimini önemli ölçüde önlediği saptanmıştır (1, 14). Bununla birlikte, yapısal modifikasyon ve potansiyel toksisitelerin gösterilmesindeki zorluklar, bugüne kadar bu ajanların herhangi biri için başarılı bir sonucu engellemiştir. Kıkırdak innervasyonunun olmadığı göz önüne alındığında, bu sözde ajanlar ilerlemeyi yavaşlatabilir ancak ağrı üzerinde doğrudan bir etkisi bulunmamaktadır. Agrekanaz aktivitesini düzenleyen yolakların teşvik edilmesi gelecekteki hedefler arasında olacaktır (2, 3). Wnt sinyal yolunun, kıkırdak ve kemik de dâhil olmak üzere eklem dokusu oluşumunda merkezi bir rol oynadığı bilinmektedir. Kıkırdak kalınlığında ve diz ağrısında bir miktar iyileşme, Wnt inhibitörü SM04690'ın intraartiküler enjeksiyonunun küçük ölçekli bir çalışmasında bildirilmiştir. SM04690, kondrogenezi indüklemiş ve bir $\mathrm{OA}$ modelinde eklem yıkımını önlediği görülmüştür. OA için potansiyel bir hastalık modifiye edici terapi için bir aday olarak görülmektedir. 
İntraartiküler olarak uygulanan çalışmalarda; ağrı ve eklem aralığına etkili ve güvenli olduğu görülmüştür (15). TPX-100, insanlarda doğal olarak bulunan, sert doku ve fosfat metabolizmasının düzenlenmesinde rol oynadığı bilinen bir protein olan matriks hücre dışı fosfoglikoproteinden (MEPE) türetilmiş yeni bir 23-amino asit peptidtir. İntraartiküler kullanımın kıkırdak kalınlığını arttırdığı, analjezik kullanım intiyacını azalttığı, fonksiyonlarda düzelme sağladığı gösterilmiştir $(1,16)$. Kemik morfogenetik protein 7 veya BMP7 (ayrıca osteojenik protein-1 veya OP-1 olarak da bilinir), insanlarda BMP7 geni tarafından kodlanan bir proteindir. BMP-7, TGF- $\beta$ süper ailesinin bir üyesidir. Kemik morfogenetik protein ailesinin diğer üyeleri gibi, mezenkimal hücrelerin kemik ve kıkırdakta dönüşümünde, homeostazında anahtar rol oynamaktadır. Preklinik çalışmalarda anabolik ve antikatabolik aktivitesi olduğu görülmüş fakat klinik çalışmalarda ispatlanamamıştır $(2,17)$. Diaserin, kıkırdak ve sinoviyal membranda anti-inflamatuvar, anti-katabolik ve proanabolik özellikleri olan, osteoartrozda semptomatik, yavaş etkili bir ilaçtır. Diaserin in vivo ve in vitro çalışmalarda, osteoartroz gibi dejeneratif eklem hastalıklarının semptomlarının gelişiminde rol oynayan bir protein olan IL-1 $\beta$ 'nin etkisini bloke ederek çalışır ve kondrositler tarafından IL-1 $\beta$ kaynaklı NO üretiminin güçlü bir inhibitörüdür. Subkondral kemikte proinflamatuar sitokin ve MMP-13 üretimini bloke ederek etki göstermektedir. Diaserin in vitro ve hayvan modellerinde anti-osteoartroz ve kıkırdak uyarıcı özelliklere sahip olduğu gösterilmiştir. Klinik denemelerinde, diaserinin etkinliğinin, tedavinin ilk ayından sonra steroidal olmayan anti-inflamatuvar ilaçların (NSAii) etkisine benzer olduğunu ve parasetamolden daha üstün olduğunu doğrulamıştır. Ek olarak, diaserin tedavi durdurulduktan sonra birkaç ay daha semptomlar üzerinde etkili göstermiştir (18). Glukozamin sülfat / kondromin sülfat; kıkırdakta anabolizma-katabolizma dengesi üzerine etkilidir. Proteoglikan bileşenlerinin üretimini stimüle etmektedir. Kondrositlerde MMP-13 aktivitesini, proinflamatuar sitokin üretimini, ADAMTS-4 ve ADAMTS-5 inhibe etmektedir. TIMP-1 ve TIMP-3 gen ekspresyonunu artırmaktadır. Diz OA'u yönetimi için ESCEO (The European Society for Clinical and Economic Aspects of Osteoporosis, Osteoarthritis and Musculoskeletal Diseases) algoritmasına göre ağrı skorları ve fonksiyonel durumda iyileşme için üç yıllık kullanımda, plasebo ile karşılaştırılığında eklem aralığında daralmada azalma saptanmıştır. En az 12 aylık kullanımda cerrahi tedaviye giden hasta sayısında azalma, 5 yıllık kullanımda da plasebo grubuna göre diz artroplasti gereksiniminde yarı yarıya azalma olduğu gösterilmiştir. Hafif ve orta düzey OA için glukozamin sülfat $(1500 \mathrm{mg}$ ) ve kondromin sülfat 1200 mg olarak kombine tedavide etkinlik artmakta, eklem aralığında daralmada belirgin azalma, kıkırdak volümünün azalmasında belirgin düşüş saptanmıştır. Yapılan çalışmalarda güvenli ve plasebo ile benzer yan etki profili olduğu görülmüştür $(1,2,19)$.

\section{Sinoviyum}

Lubricin, kıkırdak bütünlüğünde önemli bir rol oynayan, sinoviyal eklemden salgılanan bir müsin glikoproteinidir. Sağlıklı eklemlerde kıkırdak yüzeyini kaplar ve hücre protein yapışmasını önler. Eklem kıkırdağına zarar gelmesini önleme, kondrositleri koruma özelliğine sahiptir. Farmakolojik tedavi ağrıyı hafifletemediğinde, viskosuplementasyon (VS) bir seçenek olabilmektedir. VS, sinoviyal sıvının reolojik özelliklerini değiştirmek veya güçlendirmek ve eklem işlevselliğini geliştirmek için eklemin eklem içi boşluğuna bir viskoelastik çözeltinin enjekte edildiği terapötik bir yöntemdir. Ağrı, fonksiyon, hasta global değerlendirme sonuçları olumlu saptanmıştır fakat mekanik ve farmakolojik etkisi yavaş başlamakta ve altı ay devam etmektedir (20). Uluslararası Osteoartroz Araştırma Topluluğu (OARSI)'na göre; diz OA'u için belirsiz etkiye sahip olduğu, olguya göre karar verilmesi gerektiği, ESCEO önerilerine göre hafif-orta diz OA'sında cerrahi tedavi intiyacını geciktirdiği belirtilmiştir. Hyalüronik asit ve kortikosteroid etkileri karşılaştırıldığında; erken dönemde (birinci ayda) kortikosteroid daha etkili bulunmuş iken, altıncı ay hyalüronik asit ağrı açısından daha etkili bulunmuştur. Diz fonksiyonu açısından iki tedavi de birbirine benzer etkili ve güvenli olup, topikal yan etkiler HA grubunda daha fazla bulunmuştur (21). İnterlökin-1 (IL-1), romatoid artrit patogenezinde rol oynayan primer bir sitokin olup, inflamasyon ve eklem tahribatına neden olmaktadır. Anakinra (AMG108), IL-1'in biyolojik aktivitesini bloke eden bir IL-1 reseptör antagonistidir. Preklinik çalışmalarda IL-1ß'nın; OA gelişimini engellediği veya geciktirdiği gösterilmiş olmakla birlikte, yapılan klinik çalışmalarda etkisiz olduğu belirtilmiştir. Anakinranın ilaç yarı ömrü çok kısa (dört saat) olup, AMG 108 için yeterli sinoviyal SIVı konsantrasyonu oluşmamakta, derin kıkırdak tabakalarına penetrasyonu şüpheli olup, klinik çalışmalarda kıkırdak üzerine etkisi araştırımamıştır. AMG 108 ile yapılan çalışmada; nötropeni ve lober pnömoni nedeniyle hastanın kaybedilmesi üzerine her iki IL-1 inhibitörünün $O A$ 'da kullanımı ile ilgili klinik programlar durdurulmuştur (22). Infliximabın preklinik olarak intraartiküler kıkırdak lezyonlarını azalttığı ortaya konmuştur. Adalimumab ile yapılan klinik çalışmalarda; ağrı ve radyolojik progresyonu azaltmada yetersiz bulunmuştur. Etanercept (SC, IA) ile ilgili klinik çalışmalarda ağrıyı azaltmada yetersiz bulunmuştur (23).

\section{Ağrı}

Klinik çalışmalarda birincil sonuç olarak görülen ağrı, yerleşik hastalıkta yapısal modifikasyondan daha fazla kabul görmekte ve izlenmektedir. Ağrı, hastalar için en önemli şikayettir. OA ve diğer kronik ağrılı durumlarda 
ağrıyı hafifletme yolu kemik ve sinoviyum gibi spesifik eklem dokularındaki değişiklikler tarafından yönlendirilebilse de, duyusal afferentleri aktive eden primer nörotrofik yolakların hedeflenmesinin oldukça etkili olabileceğine dair kanıtlar da vardır. Fare modellerinden sinir büyüme faktörü (NGF) ve diğer nörotrofinlerin semptomatik hastalıklarda aşırı salındığı ve eklem bağ dokusu tarafından kendilerinin sentezlendiğine dair kanıtlar vardır. NGF hiperaljeziye neden olmaktadır. NGF veya kalsitonin geni ile ilişkili peptidin (CGRP) inhibisyonu preklinik modellerde ağrı davranışını azaltmaktadır. İnsanlarda en çok çalışılan alan NGF inhibisyonudur. NGF monoklonal antikoru olan tanezumabın deri altından uygulanmasının, diz OA'unda klinik olarak önemli miktarda ağrıyı hafiflettiği gösterilmiştir. Daha sonraki denemelerde tanezumab NSAili'lara ve opiyatlara üstünlük göstermiştir $(4,24)$. Fasinumab gibi NGF'ye etkin diğer monoklonal antikorlar ve çözünür tropomiyosin reseptörü kinaz $A$ (TrkA) reseptör füzyon proteinleri de benzer etkiler göstermiştir. Potansiyel bir osteonekroz güvenlik sinyali nedeniyle Faz III çalışması FDA tarafından durdurulmuştur. Daha ileri çalışmalar pregabalin ve duloksetinin el OA'undaki etkilerini ve etki mekanizmalarını karşılaştırmaktadır. Osteoartroz tedavisinde sıklıkla reçete edilen analjeziklerin ağrı üzerine etkinliği ile ilgili 2018 de yapılan sistematik inceleme ve meta analiz sonucunda; asetaminofen, oral NSAil, Cox-2 inhibitörü, opioidlerin etkinliği hemen hemen birbirine yakın; topikal NSAil'ların ise diğerlerinden daha etkin olduğu gösterilmiştir $(1,2,4$, 25).

\section{İnflamasyon}

OA'da inflamasyon şaşırtıcı derecede tartışmalı bir konudur. İnflamasyonun hastalığın başlamasında ve geç hastalıkta önemli olduğuna dair kanıtlar vardır. Yüksek sistemik inflamatuvar sitokin seviyeleri [örneğin interlökin (IL)-6 ve tümör nekroz faktör- $\alpha$ (TNF- $\alpha$ )] hastalığın ilerlemesi ile ilişkilidir. Bu moleküller agrekanazların aktivasyonunu indükleyebilmektedir. İlerlemiş hastalık aktivitesinde, sinoviyal inflamasyon, ağrının en güçlü habercilerinden biri gibi görünmektedir. Anti-inflamatuvar etkiyle NSAii ve steroidlerin ağrı üzerinde etkinliği kanıtlanmıştır fakat mevcut ilaçların hastalık değiştirici etkileri olduğu düşünülmemektedir. RA'da kullanım için lisanslı birkaç anti-sitokin ilaç OA'da incelenmiştir. Adalimumabın aktif kolunda \%35.1, plasebo kolunda \%27.3 ağrı azalması görülmüştür ve adalimumabın plaseboya göre daha üstün olmadığı sonucuna varılmıştır (26). Son zamanlarda yapılan küçük hasta gruplu bir çalışmada diz OA'sı için tek bir intra-artiküler etanersept enjeksiyonunun, intra-artiküler hyaluronan ile karşılaştırıldığında ağrı VAS'ında belirgin bir azalma olduğu görülmüştür $(4,27)$. IL-1R1'e karşı bir insan monoklonal antikorunun, 12 hafta boyunca diz OA'sı olan 159 kişide, plaseboya karşı belirgin bir fayda göstermediği bildirilmiştir. Selektif bir oral indüklenebilir nitrik oksit sentaz (iNOS) inhibitörü olan cindunistatın, eklem boşluğu daralması, ağrı ya da fonksiyon üzerinde bir etkisi olmadığı gösterilmiştir. Cindunistat, OA gelişiminde makrofajlar dahil olmak üzere doğal bağışıklığa neden olabilmektedir $(1,28)$. Kolşisin, kısmen inflamatuar yolla etkisi olan eski bir ilaçtır. Bu ilacın semptomatik post menopozal diz OA'sı üzerindeki etkinliği değerlendirilmektedir. Sinoviyal inflamasyonun inhibisyonu, kolsişin için önemli bir etki şekli olabilir (29). Ağrılı OA üzerindeki etkilerini değerlendirmek için mevcut anti-sinoviyal ajanların yeniden çalışmaları yapılmıştır. Diz OA'sı ve efüzyon gibi inflamatuvar bulguları olan önceden tanımlanmış bir grupta randomize kontrollü çalışmada $25 \mathrm{mg}$ metotreksat, diz ağrısı ve ultrasonda belirgin inflamasyonu azaltmada plaseboya kıyasla üstündür. Bir hidroksiklorokin çalışması ise ağrı iyileşmesi göstermediği için erken sonlandırılmıştır. El OA'sında hidroksiklorokinin, el ağrısı üzerine etkisi plaseboya göre farklı saptanmamış ve ultrasonda inflamatuvar değişiklik gösteren bir alt grupta hiçbir fark bulunmamıştır (30). Bozulmuş mikrovasküler sisteminin, bireyleri OA'ya önceden tanı koymada önemli olabilir düşüncesi bulunmaktadır. Vasküler antiinflamatuvar etkiye sahip olan diğer ilaçların OA'ya faydası olabileceği hipotezi bulunmaktadır. Bu ilaçlar: atorvastatin, düşük moleküler ağırlıklı heparin, aldosteron antagonisti spironolakton ve sodyum kanalı bloke edici VX-150'dir (4, 31).

\section{Tamir- Remodülasyon}

Onarım ve anti-katabolik yollar, inflamatuvar yanıtın bir parçası olarak aktive edilir ve bu yolların etkilerinin kullanılması terapötik olarak önemli olabilir. OA ve hasarlı bağ dokularında aktive edilmiş, iyi tanımlanmış iki onarıcı veya anti-katabolik yol, fibroblast büyüme faktörü (FGF) ve transforme büyüme faktörü-beta (TGF- $\beta$ )'dır. Çoklu aile üyelerinin ve alıcılarının göreceli rolleri hakkında öğrenilecek çok şey bulunmaktadır. Her iki yol da pleiotropiktir: FGF-2'nin dağıtıması, OA'yı hızlandırır, ancak FGF'ler, bağ dokusu hasarına karşı inflamatuvar sinyalleşme yanıtına katkıda bulunur. Benzer şekilde, TFG- $\beta$ ve ailesi eklem kıkırdağı için anti-katabolik olabilir ve kıkırdak büyümesini, kemik büyümesini (osteofitleri teşvik eder) ve fibrozisi teşvik edebilir. $\mathrm{Bu}$ alanda yayınlanan ilk klinik çalışma, diz OA'sındaki intraartiküler FGF-18'i (sprifermin) test etmiş ve ajan iyi tolere edilmiştir. Tüm aktif tedavi grupları, 12 ayda plasebodan anlamlı farklılık göstererek ağrı skorlarını iyileştirmiştir. Tip II kollajen ve proteoglikan sentezini artırma, kıkırdak kaybında azalma ve kıkırdak kalınlığında artış, ağrıda düzelme olduğu gösterilmiştir. Bu nedenle, sprifermin Faz III değerlendirmesine geçmiştir. Spermidin, EP300 ile yaşlı ve osteoartritik kondrositlerde düzensiz otofaji ve poliamin sentezini geri kazandırır. Kondrosit polyamine sentezi yaşla azalmaktadır. Spermidine otofaji aktivasyonu ile kondrogenesisi sağlamakta olup, OA önlemede yüz güldürücü sonuçlar elde edilmiştir. 
Miyopati, nörodejenerasyon, yaş ilişkili T hücre cevap defektlerinin ilacın kullanımı açısından sorun yaratabileceği düşünülmektedir $(1,2,32)$.

\section{Herbal Terapi}

Bitkisel ilaçlara ilgi artmakta ve hasta odaklı alternatif tedaviler araştırmalarına ilgi yoğunlaşmaktadır. 2016'da yayınlanan Cochrane derlemeye göre OA tedavisinde bitkisel moleküllerin (avakado, soya ekstresi, boswellia serrata) orta düzeyde kanıtlara göre ağrı ve fonksiyonda hafif etkili, eklem aralığının korumasında ise etkisiz olduğu gösterilmiştir. Zerdeçal ve resveratrol de dahil olmak üzere bitki kaynaklı kimyasalların potansiyel profilaktik özellikleri ve bunların OA'da NF-KB sinyalini, MMP inhibisyonunu ve inflamasyonu hedeflemede kullanımları da gözden geçirilmiştir (33). Resveratrol için mevcut klinik veriler, gelecekteki klinik çalışmalara dahil edilmesini teşvik etmekte ve desteklemektedir. Diz OA'sından kaynaklanan ağrı ve sertlik tedavisinde yumurta kabuğu zarı randomize, çok merkezli, çift kör, plasebo kontrollü klinik çalışmaya göre, dizi ile ilişkili ağrı ve sertliğin tedavisi için etkili ve güvenli bir seçenek olarak görülmüştür. Günde bir kez alınan 500 mg yumurta kabuğu zarı takviyesi, 10,30 ve 60 . günlerde plaseboya kıyasla hem eklem ağrısını hem de sertliği önemli ölçüde azaltmıştır $(4,34)$.

\section{Rejenerasyon ve Kombine Tedavi}

Rejenerasyon ve kombine tedavi, eklem işlevinin onarım ve restorasyonunun ötesine geçmeyi amaçlamaktadır. Amacı doku rejenerasyonunu başlatmaktır. Kombine stratejilerin ilkesi birkaç bileşenin eşzamanlı kullanımıdır. $\mathrm{Bu}$ bileşenler hücreleri, parçacıkları ve biyoaktif maddeleri içerir. Rejeneratif tıp, patolojik dokuların onarımını doğal tamir yollarının stimülasyonu veya biyomühendislik yoluyla elde edilen ürünlerin uygulanmasını içeren gelişmekte olan bir alandır. PRP (Platelet-Rich Plasma), proloterapi ve kök hücre tedavileri bu grupta yer almaktadır $(2,35)$.

\section{$\underline{P R P}$}

PRP yara iyileşmesini artırmaktadır. Yara iyileşmesi üç faz içermektedir. Birinci faz 0-2. günlerde olan inflamatuvar faz olarak adlandırılır. Bu fazda pıhtı oluşumu, platelet aktivasyonu, nötrofil ve makrofaj invazyonu, debrisin fagositozu gerçekleşir. İkinci faz 2 . gün-6. hafta arasında olan proliferasyon fazıdır ve fibroblast proliferasyonu, kollajen birikimi gerçekleşir. 3 . faz ise aylar yıllar içinde gerçekleşen remodelling fazıdır. Bu fazda da hücresel ve vasküler komponentte azalma, tip 1 kollajende ve çapraz bağlarda artış gerçekleşir. Randomize kontrollü çalışmaların sistematik incelemesinde, PRP tedavisi ile orta dereceli OA hastalarında ağrı, fiziksel fonksiyon ve sertlik dahil klinik sonuçlarda istatistiksel olarak anlamlı gelişmeler göstermiş, genç hastalarda PRP daha etkin olup, ileri vakalarda etkisiz olduğu görülmüştür. Etkilerin 12 aya kadar devam ettiğini belirten sonuçlar bulunmaktadır.
PRP grubunda lokal yan etkilerin daha fazla olduğu saptanmıştır $(2,4,35)$.

\section{Proloterapi}

Mekanizması ile ilgili kesin veriler bulunmamaktadır. Sistematik derleme ve meta-analiz sonuçlarına göre, hipertonik dekstroz enjeksiyonları-proloterapinin, serum fizyolojik enjeksiyon ve egzersiz ile karşılaştırıldığında, diz OA tedavisinde anlamlı bir yararlı etki sağladığını göstermektedir (kanıt düzeyi orta). Bununla birlikte, bu çalışma sonuçları arasında heterojenite olduğu görülmüş olup uzun süreli etkileri konusunda bilgi bulunmamaktadır. Proloterapinin genel tedavi etkisinin daha kapsamlı bir değerlendirmesi için daha düzgün, uzun süreli çalışmalar ile eşit sonuçlar ve yüksek metodolojik standartlar gerekmektedir $(1,36)$.

\section{Kök hücre}

Kök Hücre tedavilerinin kullanımı daha çok olgu serileri düzeyinde yapılmış ve az sayıda randomize kontrollü çalışmalar mevcuttur. Sonuçlar umut verici olup çalışmalar devam etmektedir. Mezenkimal kök hücreler (MSC'ler), kas-iskelet dokularına farklılaşabilen endojen bir progenitör popülasyonudur. Önemli bir araştırmada, bu hücrelerin lokal inflamatuvar yanıtın modülasyonu yoluyla önemli immünolojik fonksiyonları da düzenlediğini göstermiştir. Bu özellikler göz önüne alındığında, MSC'ler OA hastaları için potansiyel bir rejeneratif hücre tedavisi kaynağı olarak önerilmiştir. Araştırmalar, MSC'ler birkaç dokuya özgü olduğundan, türetme için ideal kaynağı belirlemeye odaklanmıştır. Mezenkimal kök hücreler kondrojenik aktivite yerine kondrosit hipertrofisi gösterirler. Kıkırdak ve sinoviyum aynı havuz gen profiline sahiptir; sinoviyum yeni hücre kaynağı olarak düşünülmektedir $(3,4)$. Kondrojenik aktivitenin NFAT1 ve NFAT2 genlerinden eksprese edildiği gösterilmiştir. Tendinopatilerde etkinliği ile ilgili çok sayıda çalışma bulunmaktadır. OA etkinliği ile ilgili çalışmaların kalitesi henüz yeterli düzeyde değildir. MSC tedavisinin bazı kısıtlamaları mevcuttur. Hücre dozu, sayı, zamanlama, kostimulatör (HA ile uygulama), hücre subtipi, hastalık evresi, tedavi etkisi ve takibi gibi soru işaretleri bulunmaktadır. OA için genetik yatkınlık ve yaşı kişilerde hücre kalitesi de göz önüne alınarak ne derece etkili olabileceği düşünüldüğünde ileri dönemde güvenlik açısından tartışmalar bulunmaktadır $(2,3,37)$.

\section{Ozon Tedavisi}

Ozonun birçok hastalıkta ve özellikle diz OA'sı gibi kasiskelet sistemi rahatsızlıklarının tedavisinde uzun zamandır klinik kullanımı vardır. Ozon, inflamatuvar sitokinleri, MMP'yi (metal metaloproteinazlar), NO'yu (nitrik oksit), PG'leri inhibe edebilir ve anti-inflamatuvar sitokinleri, büyüme faktörlerini, kondrositleri ve kök hücreleri uyarabilir. Ozon, inflamasyonu azaltır ve eklem kıkırdak ve subkondral kemiğin tropizmini, vaskülarizasyonunu ve onarımını kolaylaştıır. Ozonun diz OA'sındaki farklı hedefler üzerindeki etkisi, onu 
ağrıyı, eklemlerin yıkımını azaltabilen ve işlevini ve yaşam kalitesini geri alabilen umut verici ve harika bir tedavi edici silah olarak varsaymaktadır. Ozon tedavisinin, farklı tıbbi uzmanlıklarda (diz OA'sı dahil) beklenen tüm potansiyelleri nedeniyle, yaygın bir tedavi olacağı umudu vardır. Hafif-orta diz OA'sında daha etkili olacağı söylenebilir. Yan etkileri ile ilgili kesin veriler bulunmamaktadır. Farklı uygulama protokolleri olması standardizasyonu güçleştirmektedir. Uzun dönem etkileri ile ilgili veri yoktur $(2,38)$.

\section{Gen Terapisi}

Bazı yazarlar OA'da gen terapisi konusundaki deneyimlerini bildirmişlerdir ve eğer doğru vaka seçimi yapılabilirse, ek tedavi olarak bir seçenek olduğu görülmektedir. İnhibitör ve katabolik yol inhibisyonu, anabolik yol stimulasyonu, hücre senesens ve apopitoz önleme amaçlı gen tedavisi yapılabileceği düşünülmektedir.

Derleme ve otör önerilerine göre; PRP hücre bazlı bir tedavidir, ağrı ve yaşam kalitesinde düzelme sağlamaktadır. PRP yapılan çalışmalarda umut verici olup, optimal formulasyon henüz bilinmemektedir. Glukozamin +/- kondroidin tedavileri, kısa dönemde ağrı, fonksiyon, yaşam kalitesinde düzelme gösterirken; uzun dönem etkileri bilinmemektedir. Sülfat formlarındaki preperatlar ise hidroklorid formlarına göre daha etkili bulunmuştur. Ağrıda en etkili tedavi yöntemi intraartiküler uygulamalardır (2, 3). İntraartiküler HA 1500-6000 kDa enjeksiyonu en etkili tedavi olarak gösterilmiştir. Proloterapinin ağrı ve fonksiyon üzerindeki kısa-uzun dönem üzerine etkisi olup, orta düzey kanıtlarla gösterilmiştir. SM04690; semptom kontrolü, eklem aralığı etkisi, iyi tolerasyon nedeniyle gelecekte iyi bir seçenek olabilir. İntraartiküler steroid, iki yıl (3 kez/yıl) uygulamalarında kıkırdakj volüm kaybı olduğu mutlaka akılda tutulmalıdır $(2,3,39)$.

\section{Sınırlamalar ve Gerçekler}

OA'daki son klinik çalışmalar klinik pratikte bize yol gösterici olmaktadır. İlk olarak, hastalığın ilaç etkilerini tahmin etmek için temel mekanizmaları anlamaya devam etmemiz gerekmektedir. Yapısal modifiye edici ajanlar, tedavinin kabul edilebilirliğini geliştirmek için potansiyel olarak ağrı giderici bir ajanla birleştirilebilir, fakat NGF karşıtı araştırmalar bize önce potansiyel etkileşimleri tam olarak idrak etmemiz gerektiğini söylemektedir. Kabul edilebilirlik, güvenlik ve etkinlik açısından her zaman bir denge vardır. OA gibi durumlarda kabul edilebilir risk nedir? NSAil'lar ve opiyatlar gibi mevcut ilaç sınıfları üzerinde kıyaslama yaparak, OA için yeni ilaçların kabul edilebilirliğini ve onaylanmasını değerlendirmede yüksek düzeyde bir hasta katılımına intiyaç vardır. Mevcut ajanların yeniden gözden geçirilmesi ile (diğer endikasyonlar için kabul edilebilir güvenlik profilleri ve OA'da potansiyel olarak olası etkileri olan) uygun maliyetli bir alan olması muhtemeldir. OA tedavisindeki en büyük zorluklardan biri hastalığın fenotipindeki ve ilerlemesindeki heterojenliktir. Hasta seçimi sürecimizde, en yüksek ilerleme riski olan (semptom veya kemik yapı) veya ilgili hastalık fenotipine (kronik ağrı, enflamasyon, metabolik sendrom, mekanik yüklenme, metabolik kemik/kıkırdak oranı baskın olma özelliklerine göre) sahip olanları sınıflandırabilmemiz gerekir. Bugüne kadarki araştırmaların çoğu diz ve kalça OA'ları için olup son dönemde el OA'sındaki ajanların denemelerinde de gözle görülür artış fark edilmeye başlamıştır. Ancak OA'ı hastaların çoğunluğunun bu ilaçlara intiyaç duymayabileceği de akılda tutulmalıdır. Gelecekte belirli tedavileri, hastalık süreçleri için geçerli biyobelirteçlerle veya belirli bir ilaç sınıfına verilen yanıtlarla daha iyi tanımlayarak, belirli gruplara kişiselleştirmemiz gerekecektir. Daha pahalı olan biyolojik müdahaleler, yalnızca maliyet etkin olduklarını ispatlarsa, örneğin diz protezi, OA ile ilişkili diğer komorbidite veya mortalite riskini geciktirir veya azaltırlarsa klinik pratikte yerlerini alacaklardır (1, 2, 40, 41).

\section{Anahtar Noktalar:}

- Ağrı tedavisinde tam etkili ve hastalık modifiye edici onaylanmış ilaç halen bulunmamaktadır.

- Tedavide tüm eklem hedeflenmektedir.

- Hastalığın erken tedavisi ve kombine tedaviler önem kazanmıştır.

- Fenotip, heterojenite ve hastalık progresyonu tedavi başarısının kısıtıııkları arasındadır.

- OA'da semptomları ve hastalık sürecini yeni farmakolojik ajanlarla değiştirme fırsatları yakın ufukta görünmektedir.

- Yeni ajanların altta yatan hastalık süreci üzerindeki etkisinin ne olduğunu ve bize hastalık patogenezi hakkında ne öğretebileceklerini anlamak, değerlendirmelerinin önemli bir parçasıdır.

\section{Kaynaklar}

1. Watt FE, Gulati M. New Drug Treatments for Osteoarthritis: What is on the horizon? EMJ 2017;2: 50-8.

2. Ondresik M, Maia FRA, Morais AS, et al. Management of knee osteoarthritis. Current status and future trends. Biotechnol Bioeng 2017;114:717-39.

3. Cucchiarini M, Henrionnet C, Mainard D, et al. New trends in articular cartilage repair. J Exp Orthop 2015; 2:8. DOI 10.1186/s40634-015-0026-0

4. Mobasheri A. The Future of Osteoarthritis Therapeutics: Targeted Pharmacological Therapy. Curr Rheumatol Rep 2013;15:364. doi: 10.1007/s11926-013-0385-4. 
5. Smith SR, Deshpande BR, Collins JE, Katz JN, Losina E. Comparative pain reduction of oral non-steroidal anti-inflammatory drugs and opioids for knee osteoarthritis: systematic analytic review. Osteoarthritis Cartilage 2016;24(6):962-72.

6. Bingham CO, Buckland-Wright JC, Garnero P, et al. Risedronate decreases biochemical markers of cartilage degradation but does not decrease symptoms or slow radiographic progression in patients with medial compartment osteoarthritis of the knee: results of the two-year multinational knee osteoarthritis structural arthritis study. Arthritis Rheum 2006;54(11):3494-507.

7. Rossini M, Adami S, Fracassi E, et al. Effects of intra- articular clodronate in the treatment of knee osteoarthritis: results of a double- blind, randomized placebo-controlled trial. Rheumatol Int 2015;35(2):255-63.

8. Laslett LL, Kingsbury SR, Hensor EM, Bowes MA, Conaghan PG. Effect of bisphosphonate use in patients with symptomatic and radiographic knee osteoarthritis: data from the Osteoarthritis Initiative. Ann Rheum Dis 2014;73(5):824-30.

9. Walzer SM, Weinmann D, Toegel S. Medical Plant Extracts for Treating Knee Osteoarthritis: a Snapshot of Recent Clinical Trials and Their Biological Background. Curr Rheumatol Rep 2015;17(18):54. doi: 10.1007/s11926-015-0530-3.

10. Pelletier JP, Roubille C, Raynauld JP, et al. Disease-modifying effect of strontium ranelate in a subset of patients from the Phase III knee osteoarthritis study SEKOIA using quantitative MRI: reduction in bone marrow lesions protects against cartilage loss. Ann Rheum Dis 2015;74(2):422-9.

11. Roubille C, Pelletier JM, Raynauldet JP, et al. Meniscal extrusion promotes knee osteoarthritis structural progression: protective effect of strontium ranelate treatment in a phase III clinical trial. Arthritis Res Ther 2015;17:82. doi: 10.1186/s13075-015-0579-4

12. Bijlsma JW, Berenbaum F, Lafeber FP. Osteoarthritis: an update with relevance for clinical practice. Lancet 2011;377(9783):2115-26.

13. Lark MW, Bayne EK, Flanagan J, et al. Aggrecan degradation in human cartilage. Evidence for both matrix metalloproteinase and aggrecanase activity in normal, osteoarthritic, and rheumatoid joints. J Clin Invest 1997;100(1):93-106.

14. Nagase H, Kashiwagi M. Aggrecanases and cartilage matrix degradation. Arthritis Res Ther 2003;5(2):94-103.

15. Stanton H, Rogerson FM, East CJ, et al. ADAMTS5 is the major aggrecanase in mouse cartilage in vivo and in vitro. Nature 2005;434(7033):648-52.

16. Swearingen CJ, Majumdar S, Simsek I, et al. Radiographic Outcomes from a Randomized, Double-Blind, Placebo-Controlled, Phase 1 Study of a Novel, Intra-Articular, Injectable, Wnt Inhibitor (SM04690) in the Treatment of Osteoarthritis of the Knee. Abstract 2350. ACR/ARHP Annual Meeting, 2016. Washington, DC.

17. Cook SD. Preclinical and clinical evaluation of osteogenic protein-1 (BMP-7) in bony sites. Orthopedics 1999;22:669-671.

18. Fidelix TS, Soares BG, Trevisani VF. Diacerein for osteoarthritis. Cochrane Database Syst Rev 2006;1, CD005117.

19. Fransen M, Agaliotis M, Nairn L, et al. Glucosamine and chondroitin for knee osteoarthritis: a double-blind randomised placebocontrolled clinical trial evaluating single and combination regimens. Ann Rheum Dis 2015 May;74(5):851-8.

20. Ciullini Mannurita S, Vignoli M, Bianchi L, et al. CACP syndrome: identification of five novel mutations and of the first case of UPD in the largest European cohort. Eur J Hum Genet 2014;22(2):197-201.

21. He WW, Kuang MJ, Zhao J, Sun L, Lu B, Wang Y. Efficacy and safety of intraarticular hyaluronic acid and corticosteroid for knee osteoarthritis: A meta-analysis. Int J Surg 2017 Jan 27;39:95

22. Cardiel M, Tak P, Bensen W, et al. A phase 2 randomized, double-blind study of AMG 108, a fully human monoclonal antibody to IL-1R, in patients with rheumatoid arthritis. Arthritis Res Ther 2010; 12(5): R192.

23. Gilbert A, Bikker A, Neil S. Advances in the development of novel aggrecanase inhibitors, Expert Opin Ther Pat 2011; 21:1-12.

24. Burleigh A, Chanalaris A, Gardiner MD, et al. Joint immobilization prevents murine osteoarthritis and reveals the highly mechanosensitive nature of protease expression in vivo. Arthritis Rheum 2012;64(7):2278-88.

25. Walsh DA, Mapp PI, Kelly S. Calcitonin gene-related peptide in the joint: contributions to pain and inflammation. $\mathrm{Br} \mathrm{J} C$ lin Pharmacol 2015;80(5):965-78.

26. Chong KW, Chanalaris A, Burleigh A, et al. Fibroblast growth factor 2 drives changes in gene expression following injury to murine cartilage in vitro and in vivo. Arthritis Rheum 2013; 65(9):2346-55.

27. Chevalier X, Ravaud $P$, Maheu E, et al. Adalimumab in patients with hand osteoarthritis refractory to analgesics and NSAIDs: a randomised, multicentre, double-blind, placebo-controlled trial. Ann Rheum Dis 2015;74(9):1697-705.

28. Hellio le Graverand MP, Clemmer RS, Redifer P, et al. A 2-year randomised, double-blind, placebo- controlled, multicentre study of oral selective iNOS inhibitor, cindunistat (SD-6010), in patients with symptomatic osteoarthritis of the knee. Ann Rheum Dis 2013;72(2):187-95.

29. Neogi T. The epidemiology and impact of pain in osteoarthritis. Osteoarthritis Cartilage 2013;21(9):1145-53.

30. Watt FE, Ismail HM, Didangelos A, et al. Src and fibroblast growth factor 2 independently regulate signaling and gene expression induced by experimental injury to intact articular cartilage. Arthritis Rheum 2013;65(2): 397-407.

31. Goldring MB. The role of cytokines as inflammatory mediators in osteoarthritis: lessons from animal models. Connective Tissue Res 1999;40(1):1-11.

32. Sacitharan $P$, Lwin S, Gharios GB, Edwards JR. Spermidine restores dysregulated autophagy and polyamine synthesis in aged and osteoarthritic chondrocytes via EP300 Exp Mol Med 2018;50(9): 123. doi: 10.1038/s12276-018-0149-3.

33. Long L, Soeken K, Ernst E. Herbal medicines for the treatment ofosteoarthritis: a systematic review. Rheumatology (Oxford) 2001;40(7):779-93.

34. Whitehouse MW, Butters DE. Combination anti-inflammatory therapy: synergism in rats of NSAIDs/corticosteroids with some herbal/animal products. Inflammopharmacology 2003;11(4):453

35. Di Y, Han C, Zhao L, Ren Y. Is local platelet-rich plasma injection clinically superior to hyaluronic acid for treatment of knee osteoarthritis? A systematic review of randomized controlled trials.Arthritis Res Ther 2018;20(1):128.

36. Rabago D, Zgierska A, Fortney L, et al. Hypertonic Dextrose Injections (Prolotherapy) for Knee Osteoarthritis: Results of a Single-Arm Uncontrolled Study with 1-Year Follow-Up. Altern Complement Med 2012 Apr;18(4):408-14.

37. Sampson S, Bemden A, Aufiero D. Stem cell therapies for treatment of cartilage and bone disorders: osteoarthritis, avascular necrosis, and non-union fractures. PM R 2015;7(4 Suppl):S26-S32.

38. Fernandez-Cuadros ME, Perez-Moro OS, Mirón-Canelo JA. Could Ozone Be Used as a Feasible Future Treatment in Osteoarthritis of the Knee? Divers Equal Health Care 2016;13(3): 232-239. 
39. Vannabouathong C, Bhandari M, Bedi A, et al. Nonoperative Treatments for Knee Osteoarthritis: An Evaluation of Treatment Characteristics and the Intra-Articular Placebo Effect: A Systematic Review. JBJS Rev 2018;6(7):e5 . doi: 10.2106/JBJS.RVW.17.00167.

40. Kraus VB, Blanco FJ, Englund M, et al. OARSI Clinical Trials Recommendations: Soluble biomarker assessments in clinical trials in osteoarthritis. Osteoarthritis Cartilage 2015;23(5):686-97.

41. Kluzek S, Sanchez-Santos MT, Leyland KM, et al. Painful knee but not hand osteoarthritis is an independent predictor of mortality over 23 years follow-up of a population-based cohort of middle-aged women. Ann Rheum Dis 2015;75(10):1749-56. 